\title{
Penentuan Sektor Unggulan di Kabupaten Kepulauan Anambas
}

\section{Determination of Leading Sectors in Anambas Islands Regency}

\author{
Ruth Yuliani Hutabarat \\ Badan Pusat Statistik Kabupaten Kepulauan Anambas \\ e-mail korespondensi: ruth.hutabarat@bps.go.id
}

\begin{tabular}{|l|}
\hline Info Artikel \\
\hline Riwayat Artikel : \\
Diterima: 17 Desember 2019 \\
Disetujui: 05 Januari 2020 \\
Dipublikasikan: Januari 2020 \\
\hline Nomor DOI \\
10.33059/jseb.v11i1.1790 \\
Cara Mensitasi : \\
Hutabarat, R.Y. 2020. \\
Penentuan Sektor Unggulan \\
di Kabupaten Kepulauan \\
Anambas. Jurnal Samudra \\
Ekonomi dan Bisnis. 11(1): \\
95-110.
\end{tabular}

\begin{abstract}
Abstrak
Penelitian ini bertujuan untuk menganalisis sektor-sektor ekonomi unggulan di Kabupaten Kepulauan Anambas. Metode analisis data yang digunakan adalah analisis Location Quotient (LQ), Shift-Share, dan Tipologi Klassen dengan wilayah analisis yaitu Kabupaten Kepulauan Anambas dan wilayah referensi yaitu Provinsi Kepulauan Riau. Berdasarkan analisis LQ, diketahui bahwa sektor unggulan Kabupaten Kepulauan Anambas adalah sektor Pertanian, Kehutanan, dan Perikanan, serta sektor Pertambangan dan Penggalian. Berdasarkan analisis Shift-Share, diketahui bahwa sektor Konstruksi dan sektor Jasa Kesehatan dan Kegiatan Sosial merupakan sektor dengan pertumbuhan yang pesat, sedangkan sektor Pertanian, Kehutanan, dan Perikanan merupakan sektor yang pertumbuhannya terhambat tetapi berkembang. Berdasarkan analisis Tipologi Klassen, ditemukan bahwa Sektor Pertanian, Kehutanan dan Perikanan merupakan sektor unggulan dan memiliki pertumbuhan yang cepat. Sementara sektor Pertambangan dan Penggalian adalah sektor unggulan tetapi pertumbuhannya terhambat. sektor Konstruksi, Sektor Real Estat, dan Jasa Kesehatan dan Kegiatan Sosial yang merupakan sektor potensial dan masih dapat dikembangkan.
\end{abstract}

Kata Kunci: Sektor Unggulan Daerah, LQ, Shift-Share, Tipologi Klassen.

\begin{tabular}{|c|c|}
\hline & Abstract \\
\hline $\begin{array}{l}y: \\
\text { December } 2019\end{array}$ & $\begin{array}{l}\text { This paper aims to analyze the leading sectors of the economy in Kepulauan } \\
\text { Anambas Regency. The data analysis method used is the Location Quotient } \\
\text { (LQ), Shift-Share, and Klassen Typology, with the analysis area of Kepulauan } \\
\text { Anambas Regency and the reference area of Kepulauan Riau Province. Based }\end{array}$ \\
\hline $\begin{array}{l}\text { DOI Number: } \\
\text { 10.33059/jseb.v11i1.1790 } \\
\text { How to cite: } \\
\text { Hutabarat, R.Y. } 2020 . \\
\text { Penentuan Sektor Unggulan } \\
\text { di Kabupaten Kepulauan } \\
\text { Anambas. Jurnal Samudra } \\
\text { Ekonomi dan Bisnis. 11(1): } \\
\text { 95-110. }\end{array}$ & $\begin{array}{l}\text { on LQ analysis, it is known that the leading sector of Kepulauan Anambas } \\
\text { Regency is Agriculture, Forestry, and Fisheries sector, as well as Mining and } \\
\text { Quarrying sector. Based on Shift-Share analysis, it is known that the } \\
\text { Construction sector and Health Services and Social Activities sector are sectors } \\
\text { with rapid growth, while the Agriculture, Forestry, and Fisheries sectors are } \\
\text { stunted but growing sectors. Based on the Klassen Typology analysis, it is found } \\
\text { that the Agriculture, Forestry and Fisheries Sector is the leading sector and has } \\
\text { rapid growth. While the Mining and Quarrying sector is the leading sector but } \\
\text { the growth is stunted. The Construction sector, Real Estate sector, and Health } \\
\text { Services and Social Activities sector which are potential sectors and can still be } \\
\text { developed. }\end{array}$ \\
\hline
\end{tabular}

Keywords: Regional Leading Sector, LQ, Shift-Share, Klassen Typology. 


\section{PENDAHULUAN}

Salah satu sasaran pembangunan nasional adalah terciptanya pertumbuhan ekonomi serta pemerataan pembangunan (Marfiani et al., 2009). Agar dapat tercapainya sasaran pembangunan tersebut, diperlukan perencanaan dan strategi pembangunan ekonomi yang baik. Umumnya pembangunan ekonomi suatu daerah berkaitan erat dengan potensi ekonomi dan karakteristik yang dimiliki daerah tersebut (Marfiani et al., 2009). Nurlina et al. (2019) mengemukakan bahwa keberhasilan pembangunan ekonomi suatu daerah sangat ditentukan oleh kebijakan pembangunan yang dilakukan dengan berbagai upaya, guna menciptakan lapangan kerja yang optimal. Pembangunan daerah pada hakekatnya adalah upaya terencana meningkatkan kapasitas pemerintah daerah sehingga bisa tercipta kemampuan dalam memberikan pelayanan kepada masyarakat serta kemampuan untuk mengelola sumber daya ekonomi daerah yang berdaya guna serta berhasil guna untuk kemajuan perekonomian daerah dan kesejahteraan masyarakat (Mose et al., 2016).

Pembangunan ekonomi suatu wilayah dapat melibatkan berbagai sektor serta para pelaku pembangunan, sehingga perlu adanya kerja sama dan koordinasi yang baik di antara semua pihak yang terlibat (Nurlina et al., 2019). Kabupaten Kepulauan Anambas yaitu wilayah Kepulauan yang memiliki tantangan tersendiri dalam pelaksanaan pembangunan, seperti sulitnya pengangkutan saat musim dan cuaca tertentu, jarak antarpulau yang cukup jauh, serta harga barang yang mahal dikarenakan sulitnya distribusi barang hingga sampai ke tangan para konsumen. Namun demikian, pemerintah telah mampu meningkatkan ketersediaan stok barang sepanjang tahun sehingga stok barang kebutuhan masyarakat 'putus' saat memasuki musim dan cuaca ekstrim tidak terjadi lagi (Sahid et al., 2019).

Potensi kekuatan ekonomi suatu wilayah tidak hanya dari kekayaan alam yang dimiliki, tetapi juga dari Sumber Daya Manusia yang dimiliki. Oleh sebab itu, diperlukan adanya SDM yang banyak dan berkualitas sebagai faktor produksi yang dapat mendorong perekonomian.

Pertumbuhan ekonomi serta prosesnya yang berkelanjutan merupakan hal yang penting bagi pembangunan suatu daerah. Pertambahan jumlah penduduk menyebabkan bertambah pula kebutuhan ekonomi, sehingga dibutuhkan ada peningkatan perekonomian daerah. Yulianita (2009) mengemukakan bahwa terdapat faktor-faktor utama yang menentukan pertumbuhan ekonomi suatu daerah, antara lain: 1) sumber daya alam yang tersedia, 2) tersedianya modal bagi pengelolaan bagi sumber daya alam, 3) adanya sarana dan prasarana (infrastruktur) penunjang aktivitas seperti transportasi dan komunikasi, 4) tersedianya teknologi yang tepat untuk pengelolaan sumber daya alam yang tersedia, dan, 5) tersedianya sumber daya manusia yang berkualitas untuk pengelolaan teknologi.

Pertumbuhan ekonomi dapat ditentukan oleh pertumbuhan basis ekspor serta eksploitasi kemanfaatan alamiah di suatu daerah, terutama dalam hal ini dipengaruhi oleh tingkat permintaan dari luar daerah (Nugroho, 2004). Dalam era otonomi daerah, perhatian terhadap pertumbuhan ekonomi daerah semakin meningkat. Hal ini terjadi karena adanya otonomi daerah membuat daerah berlomba-lomba meningkatkan pertumbuhan ekonomi daerahnya, untuk meningkatkan kesejahteraan masyarakat (Umiyati, 2014). Upaya peningkatan pertumbuhan ekonomi dapat dilakukan melalui pengoptimalan kegiatan ekonomi pada sektor-sektor unggulan. 
Berdasarkan uraian tersebut, penelitian ini bertujuan untuk menganalisis sektor ekonomi unggulan di Kabupaten Kepulauan Anambas.

\section{Sektor Unggulan}

Pertumbuhan ekonomi merupakan suatu indikator penting bagi sebuah daerah untuk menggambarkan keberhasilan pembangunan yang telah dicapai serta berguna untuk menentukan arah pembangunan di masa yang akan datang (Suryani, 2006). Rahmatullah (2012) menyebutkan bahwa struktur perekonomian daerah harus diperhatikan agar dapat meningkatkan pertumbuhan ekonomi daerah tersebut.

Terdapat dua faktor utama dalam mengindentifikasi potensi kegiatan ekonomi daerah, yaitu sektor ekonomi unggulan dan sektor ekonomi potensial (Yulianita, 2010). Sektor unggulan berkaitan dengan perbandingan, baik berskala regional, nasional, maupun internasional. Pada lingkup nasional, suatu sektor dapat disebut sebagai sektor unggulan apabila sektor di suatu wilayah mampu bersaing dengan sektor yang sama di wilayah lain (Tambunan, 2001).

Suatu daerah akan memiliki sektor unggulan apabila daerah tersebut dapat bersaing pada sektor yang sama dengan daerah lain sehingga dapat melakukan ekspor. Sektor unggulan berpotensi besar untuk tumbuh lebih cepat dibandingkan sektor lainnya dalam suatu daerah terutama karena adanya faktor pendukung terhadap sektor unggulan tersebut yaitu akumulasi modal, penyerapan tenaga kerja, dan kemajuan teknologi (Nurlina et al., 2019).

\section{Teori Basis Ekonomi}

Teori basis ekonomi membedakan antara aktivitas sektor basis dan aktivitas sektor non-basis (Jumiyanti, 2018). Dalam teori basis ekonomi atau teori basis ekspor (economic base theory), dinyatakan bahwa pertumbuhan ekonomi suatu daerah berhubungan langsung dengan permintaan akan barang dan jasa dari luar daerah.

Aktivitas sektor basis yang mampu menjual hasil produksinya ke luar daerah karena telah mampu memenuhi kebutuhan akan produk tersebut akan mempengaruhi pertumbuhan sektor tersebut, dan hal tersebut menjadi penentu pembangunan menyeluruh bagi daerah tersebut. Hal itu tentu mampu meningkatkan kesempatan kerja yang berpengaruh pada pendapatan regional. Aktivitas sektor non-basis tergantung kepada arah perkembangan yang terjadi pada sektor basis, sehingga akan menyebabkan terjadinya perubahan pada konsumsi dan investasi di daerah dimana sektor ini merupakan sektor sekunder (Yulianita, 2009). Dengan kata lain, baik sektor basis maupun sektor non-basis keduanya berhubungan dengan permintaan barang dan jasa dari luar wilayah.

Teori basis ekonomi dapat digunakan dalam penentuan sektor unggulan di Kabupaten Kepulauan Anambas. Apabila sektor unggulan tersebut dikembangkan dengan baik, tentunya akan berpengaruh sugnifikan terhadap pertumbuhan ekonomi daerah (Jumiyanti, 2018). Pertumbuhan sektor basis dan non-basis memiliki efek ganda terhadap perekonomian suatu wilayah (Yulianita, 2009). Pertumbuhan sektor basis dan non-basis dapat mendorong meningkatnya kinerja sektor-sektor lainnya yang berkaitan. Hal ini tentu dapat meningkatkan pendapatan daerah secara optimal.

\section{Produk Domestik Regional Bruto}

Produk Domestik Regional Bruto (PDRB) merupakan nilai tambah bruto seluruh barang dan jasa yang dihasilkan oleh suatu masyarakat dalam kurun waktu satu tahun yang berada di daerah atau regional tertentu yang timbul akibat berbagai aktivitas 
ekonomi. Angka Produk Domestik Regional Bruto sangat diperlukan sebagai bahan analisis perencanaan pembangunan dan juga merupakan barometer untuk mengukur hasilhasil pembangunan yang telah dilaksanakan (Nurlina et al., 2019). PDRB merupakan salah satu indikator ekonomi untuk mengukur kemajuan pembangunan di suatu wilayah.

PDRB pada tingkat regional menggambarkan kemampuan suatu wilayah untuk menciptakan nilai tambah pada suatu waktu tertentu. Untuk menyusun PDRB digunakan dua pendekatan, yaitu produksi dan penggunaan. PDRB dengan sisi pendekatan produksi atau dari sisi lapangan usaha merupakan penjumlahan seluruh komponen nilai tambah bruto yang mampu diciptakan oleh lapangan usaha atas berbagai aktivitas produksinya. Sedangkan PDRB dari sisi penggunaan menjelaskan tentang penggunaan dari nilai tambah tersebut.

PDRB disajikan dalam dua penilaian yaitu Atas Dasar Harga Berlaku (ADHB) dan Atas Dasar Harga Konstan (ADHK). Pada harga berlaku, agregat dinilai dengan menggunakan harga pada tahun berjalan sehingga nilainya dipengaruhi oleh inflasi. Harga berlaku disebut juga sebagai harga nominal. Sedangkan harga konstan didasarkan pada harga satu tahun dasar tertentu sehingga disebut sebagai harga riil. Tahun dasar yaitu tahun yang menjadi referensi statistik, digunakan sebagai dasar penghitungan tahuntahun yang lain. Kontribusi suatu sektor terhadap perekonomian diperoleh dari persentase PDRB ADHB sektor tersebut terhadap PDRB total. Sedangkan laju pertumbuhan PDRB merupakan pertumbuhan PDRB ADHK tahun n terhadap tahun n-1.

\section{Kondisi Ekonomi Kabupaten Kepulauan Anambas}

Pertumbuhan ekonomi tentu selalu diharapkan mengalami peningkatan dari tahun ke tahun. Sebagai Kabupaten termuda di Provinsi Kepulauan Riau, diharapkan level perekonomian yang dicapai oleh Kabupaten Kepulauan Anambas selalu mengalami peningkatan seiring proses pembangunan yang terjadi setiap tahunnya. Namun demikian, permasalahan yang terjadi adalah laju pertumbuhan ekonomi dari Kabupaten Kepulauan Anambas teridentifikasi terus mengalami penurunan selama lima tahun terakhir, bahkan mengalami pertumbuhan negatif pada periode 2017-2018. Kabupaten Kepulauan Anambas merupakan satu-satunya wilayah yang mengalami pertumbuhan ekonomi negatif sekaligus menjadi Kabupaten dengan laju pertumbuhan ekonomi terendah di antara kabupaten dan kota di Provinsi Kepulauan Riau.

Pertumbuhan negatif menunjukkan bahwa terjadi penurunan PDRB ADHK (2010 = 100) dari tahun sebelumnya. Hal ini tentu menjadi gambaran melesunya sektor perekonomian di Kabupaten Kepulauan Anambas. Desrindra et al. (2016) menyebutkan bahwa PDRB merupakan salah satu indikator yang digunakan dalam upaya menilai keberhasilan pembangunan di suatu wilayah.

Kabupaten Kepulauan Anambas memiliki hasil migas yang cukup besar dan memiliki kontribusi sangat besar terhadap perekonomian daerah tersebut. Keberadaan minyak bumi terbatas, tetapi memiliki peran sebagai sumber energi utama yang belum tergantikan, sehingga minyak bumi terus menjadi perhatian seluruh dunia (Roziqin, 2015). Namun daerah itu tidak bisa hanya mengandalkan sektor migas untuk menopang perekonomian karena sumber daya ini termasuk dalam golongan sumberdaya nonrenewable (Rochmaningrum, 2012), sehingga suatu saat nanti akan habis. Roziqin (2015) mengemukakan bahwa laju produksi minyak bumi terus menurun sementara laju konsumsi minyak bumi terus mengalami peningkatan 
sehingga semakin besarnya kesenjangan antara produksi dan konsumsi minyak bumi. Peningkatan konsumsi migas dikarenakan kegunaan dan manfaat dari migas sangat banyak dan hampir seluruh negara menggunakan dan membutuhkannya (Adhitama et al., 2014).

Oleh karena itu, sangat penting untuk mengetahui kinerja sektor migas dalam perekonomian serta sektor apa saja yang dikategorikan sebagai sektor unggulan dalam pembentukan perekonomian Kabupaten Kepulauan Anambas. Beberapa penelitian terdahulu dalam topik serupa telah dilakukan di wilayah lain. Sebagai contoh, Hajeri et al. (2015) melakukan penelitian mengenai analisis penentuan sektor unggulan perekonomian di Kabupaten Kubu Raya, dan menemukan bahwa sektor Industri Pengolahan, Listrik, Gas, dan Air Bersih, serta sub sektor Peternakan merupakan sektor unggulan di daerah tersebut. Riset lainnya dilakukan Nurlina et al. (2019) mengenai analisis sektor unggulan Aceh Bagian Timur, dan menyatakan bahwa sektor unggulan di Kabupaten Aceh Timur adalah sektor Pertanian, Kehutanan, dan Perikanan serta sektor Pertambangan dan Penggalian.

Optimalisasi kegiatan ekonomi pada sektor unggulan itu diharapkan mendorong sektor tersebut dapat berkembang dan menjadi sektor basis pada daerah tersebut sehingga akan berdampak pada peningkatan PDRB. Hal ini dikarenakan adanya unsur spesialisasi sesuai sektor unggulan yang dimiliki masing-masing daerah dan nantinya bisa digunakan bagi peningkatan efektivitas masyarakat dalam pelaksanaan kegiatan ekonomi (Kharisma \& Hadiyanto, 2018). Oleh karenanya, dinilai sangat penting untuk melakukan penelitian serupa di Kabupaten Kepulauan Anambas.

\section{METODE PENELITIAN}

Penelitian ini menggunakan analisis kuantitatif deskriptif. Data yang digunakan adalah data sekunder yang diperoleh dari Badan Pusat Statistik Kabupaten Kepulauan Anambas. Data yang digunakan yaitu Produk Domestik Regional Bruto (PDRB) Kabupaten Kepulauan Anambas dan Provinsi Kepulauan Riau tahun 2010 dan 2018.

Beberapa metode yang dapat digunakan untuk mengetahui sektor unggulan di suatu wilayah adalah Analisis Location Quotient (LQ), Analisis Shift-Share, dan Analisis Tipologi Klassen (Amalia, 2012). Penelitian ini menggunakan ketiga metode pengukuran data tersebut dengan wilayah analisis yaitu Kabupaten Kepulauan Anambas dan wilayah referensi yaitu Provinsi Kepulauan Riau.

\section{Analisis LQ}

Analisis LQ (Location Quotient) digunakan untuk mengidentifikasi besarnya peranan sektor perekonomian suatu wilayah (wilayah analisis) dengan membandingkan sektor yang sama pada wilayah yang lebih besar (wilayah referensi). Dalam penelitian ini, yang merupakan wilayah analisis adalah Kabupaten Kepulauan Anambas dan yang merupakan wilayah referensi adalah Provinsi Kepulauan Riau. Dengan menggunakan metode ini, dapat diketahui sektor apa yang menjadi unggulan di suatu wilayah dan sektor apa yang bukan merupakan sektor unggulan (Husna et al., 2013). Rumus penghitungannya yaitu:

$$
L Q_{i}=\frac{S_{i j} / S_{j}}{S_{i n} / S_{n}}
$$

dimana $S_{i j}$ merupakan jumlah tenaga kerja pada sektor $i$ pada wilayah analisis; $S_{j}$ merupakan jumlah tenaga kerja pada wilayah analisis; $S_{\text {in }}$ merupakan jumlah tenaga kerja 
pada sektor $i$ di wilayah referensi; $S_{n}$ adalah jumlah tenaga kerja di wilayah referensi.

Pengukuran LQ akan menggunakan tiga kriteria penilaian. Kriteria pertama yaitu jika nilai LQ > 1, maka sektor $i$ di Kabupaten Kepulauan Anambas merupakan sektor unggulan dalam menyerap tenaga kerja dibandingkan sektor yang sama di wilayah Kepulauan Riau. Kriteria kedua yaitu jika nilai $L Q=1$, maka penyerapan tenaga kerja pada sektor $i$ di Kabupaten Kepulauan Anambas adalah sama dengan penyerapan tenaga kerja pada sektor yang sama di wilayah Kepulauan Riau. Kriteria ketiga yaitu jika nilai $\mathrm{LQ} \leq 1$, maka sektor $i$ di Kabupaten Kepulauan Anambas bukan merupakan sektor unggulan dalam menyerap tenaga kerja dibandingkan sektor yang sama di wilayah Kepulauan Riau.

\section{Analisis Shift-Share}

Analisis Shift-Share merupakan salah satu metode untuk menganalisis data statistik regional untuk mengamati struktur perekonomian daerah serta perubahannya secara deskriptif. Analisis ini menitikberatkan pada pertumbuhan sektor ekonomi di suatu wilayah dan memproyeksikan kegiatan ekonomi di wilayah tersebut dengan data yang terbatas (Firdaus, 2007). Analisis ini merupakan salah satu teknik kuantitatif yang biasa digunakan untuk menganalisis perubahan struktur ekonomi suatu wilayah (wilayah analisis) terhadap struktur ekonomi suatu wilayah administratif yang lebih luas (wilayah referensi).

Dalam metode ini terdapat tiga bagian analisis. Bagian pertama adalah Regional Share (RS), yaitu komponen share pertumbuhan ekonomi daerah yang disebabkan oleh faktor eksternal. Nilai ini mengindikasikan adanya peningkatan kegiatan ekonomi daerah akibat adanya kebijakan nasional yang berlaku. Bagian kedua adalah Proportional
Shift (PS), yaitu komponen pertumbuhan ekonomi daerah yang disebabkan oleh keadaan struktur ekonomi daerah tersebut yang baik, dengan berspesialisasi pada sektor ekonomi yang pertumbuhannya cepat. Pada bagian ini, digunakan kriteria penilaian bahwa jika $\mathrm{PS}_{\mathrm{ij}}>0$, artinya sektor $i$ pada suatu wilayah analisis tumbuh lebih cepat apabila dibandingkan dengan sektor $i$ di wilayah referensi; dan sebaliknya.

Bagian ketiga dari analisis Shift-Share adalah Differential Shift (DS), yaitu komponen pertumbuhan ekonomi daerah karena adanya kondisi spesifik daerah yang kompetitif. Unsur pertumbuhan ini merupakan keunggulan kompetitif daerah yang dapat mendorong pertumbuhan ekspor keluar daerah. Pada bagian ini, digunakan kriteria penilaian bahwa jika $\mathrm{DS}_{\mathrm{ij}}>0$, artinya daya saing sektor $i$ pada suatu wilayah analisis lebih tinggi dari daya saing sektor $i$ di wilayah referensi; atau sebaliknya.

Shift Share (SS) merupakan hasil penjumlahan dari ketiga bagian tersebut. Kriteria penilaiannya adalah jika $\mathrm{SS}_{\mathrm{ij}}>0$, artinya terjadi penambahan nilai absolut atau mengalami kenaikan kinerja ekonomi daerah pada sektor $i$ di wilayah analisis tersebut. Untuk melihat keunggulan di suatu wilayah, maka keempat unsur dari analisis Shitf-Share tersebut dirumuskan sebagai berikut:

$$
\begin{aligned}
& R S_{i j}=y_{i j 0}\left(\left(Y_{t} / Y_{0}\right)-1\right) \\
& P S_{i j}=y_{i j 0}\left(\left(y_{i t} / y_{i 0}\right)-\left(Y_{t} / Y_{0}\right)\right) \\
& D S_{i j}=y_{i j 0}\left(\left(y_{i j} / y_{i j 0}\right)-\left(y_{i t} / y_{i 0}\right)\right) \\
& S S_{i j}=R S_{i j}+P S_{i j}+D S_{i j}
\end{aligned}
$$

dimana $Y_{t}$ merupakan PDRB wilayah referensi periode akhir tahun; $Y_{0}$ merupakan PDRB wilayah referensi periode awal tahun; $y_{i t}$ merupakan PDRB wilayah referensi sektor ke-i periode akhir tahun; $y_{i 0}$ merupakan PDRB wilayah referensi sektor ke-i periode awal tahun; $y_{i j t}$ merupakan PDRB wilayah 
analisis sektor ke-i periode akhir tahun; dan, $y_{i j o}$ merupakan PDRB wilayah analisis sektor ke-i periode awal tahun.

Interpretasi dari hasil analisis ShiftShare adalah: (a) Jika PSij < 0 dan DSij < 0 , artinya wilayah/sektor dengan pertumbuhan terhambat tetapi berkembang; (b) Jika PSij > 0 dan $\mathrm{DSij}<0$, artinya wilayah/sektor dengan pertumbuhan terhambat namun masih berpotensi; (c) Jika PSij < 0 dan DSij < 0, artinya wilayah/sektor dengan daya saing rendah dan peranan terhadap wilayah juga rendah; dan, (d) Jika $\mathrm{PS}_{\mathrm{ij}}>0$ dan DSij > 0, artinya wilayah/ sektor dengan pertumbuhan sangat pesat

\section{Analisis Tipologi Klassen}

Analisis Tipologi Klassen mendasarkan pengelompokan sektor ekonomi di suatu wilayah dengan cara membandingkan nilai pertumbuhan ekonomi yang dicapai wilayah analisis dengan nilai pertumbuhan ekonomi wilayah referensi serta membandingkan kontribusi sektor tersebut dengan nilai rataratanya di tingkat yang lebih luas (Emilia et al., 2014). Hasil analisis ini menunjukkan posisi pertumbuhan dan kontribusi sektor dalam membentuk perekonomian suatu wilayah.

Melalui analisis ini diperoleh empat karakteristik pola dan struktur pertumbuhan dari setiap sektor ekonomi, yaitu sektor unggulan dan tumbuh pesat, sektor unggulan tetapi pertumbuhannya tertekan, sektor potensial dan masih dapat dikembangkan, dan sektor yang tidak potensial. Untuk menentukan klasifikasi sektor digunakan matriks seperti ditunjukkan Gambar 1. Pada gambar tersebut ditampilkan bahwa $G_{i}$ merupakan pertumbuhan sektor $i$ di wilayah analisis; $G$ merupakan pertumbuhan sektor $i$ di wilayah referensi; $S_{i}$ merupakan kontribusi sektor $i$ di wilayah analisis; dan $S$ merupakan kontribusi sektor $i$ di wilayah referensi.

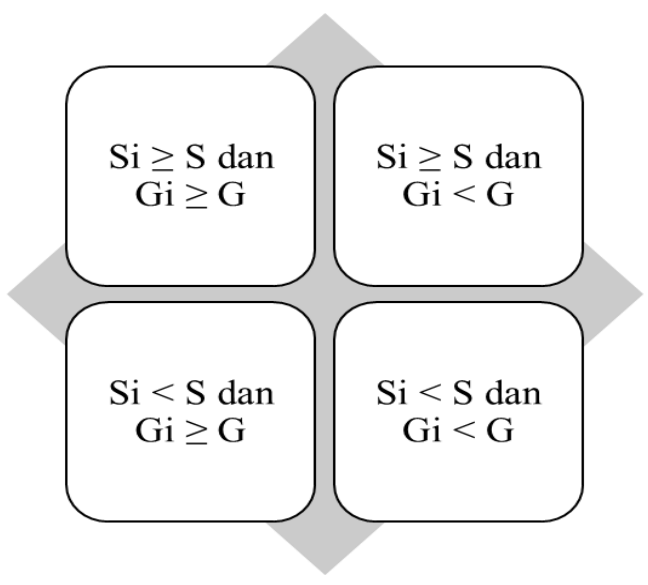

Gambar 1. Klasifikasi Tipologi Klassen

Sumber: Emilia et al., 2014.

Analisis Klassen selanjutnya akan menghasilkan empat kuadran (Aditama, 2018). Kuadran I ditempati oleh sektor dengan laju pertumbuhan ekonomi yang lebih besar dibandingkan pertumbuhan di wilayah referensi dan memiliki kontribusi terhadap perekonomian yang lebih besar dibandingkan kontribusi sektor tersebut terhadap perekonomian wilayah referensi. Sektor dalam kuadran ini dapat pula diartikan sebagai sektor yang unggulan dan tumbuh pesat.

Kuadran II ditempati oleh sektor dengan laju pertumbuhan ekonomi yang lebih rendah dibandingkan pertumbuhan di wilayah referensi dan memiliki kontribusi terhadap perekonomian yang lebih besar dibandingkan kontribusi sektor tersebut terhadap perekonomian wilayah referensi. Sektor dalam kuadran ini dapat pula diartikan sebagai sektor unggulan tetapi pertumbuhannya tertekan.

Kuadran III ditempati oleh sektor dengan laju pertumbuhan ekonomi yang lebih rendah dibandingkan pertumbuhan di wilayah referensi dan memiliki kontribusi terhadap perekonomian yang lebih rendah disbandingkan kontribusi sektor tersebut terhadap perekonomian wilayah referensi. Sektor dalam kuadran ini bukan merupakan sektor potensial dan tertinggal. 
Kuadran IV ditempati oleh sektor dengan laju pertumbuhan ekonomi yang lebih rendah dibandingkan pertumbuhan di wilayah referensi dan memiliki kontribusi terhadap perekonomian yang lebih besar dibandingkan kontribusi sektor tersebut terhadap perekonomian wilayah referensi. Sektor dalam kuadran ini dapat pula diartikan sebagai sektor potensial dan masih dapat dikembangkan.

\section{HASIL ANALISIS}

\section{Perkembangan Perekonomian Kabupaten Kepulauan Anambas}

Struktur perekonomian menggambarkan peranan sektor ekonomi terhadap pembentukan PDRB di suatu wilayah dan juga dapat menggambarkan sektor-sektor apa saja yang menggerakkan perekonomian suatu wilayah. Peranan masing-masing sektor terhadap PDRB dapat dilihat dari sumbangan yang diberikan oleh masing-masing sektor terhadap pembentukan PDRB setiap tahunnya atau dengan menghitung distribusi sektor tersebut terhadap PDRB. Semakin besar distribusi suatu sektor ekonomi, maka semakin besar pula tingkat ketergantungan perekonomian suatu daerah terhadap kemampuan berproduksi sektor ekonomi tersebut.

Bila melihat distribusi PDRB pada Kabupaten Kepulauan Anambas tahun 20162018, terlihat bahwa sektor Pertambangan dan Penggalian menjadi penopang perekonomian Kabupaten Kepulauan Anambas selama tiga tahun terakhir dan Industri Pengolahan menempati urutan kedua selama tahun 20162017. Hal ini dikarenakan Kabupaten Kepulauan Anambas merupakan wilayah operasi hulu migas di Provinsi Kepulauan Riau. Terdapat pangkalan perusahaan migas di Matak serta sejumlah tambang migas lepas pantai di perairan Kabupaten Kepulauan Anambas. Hasil migas yang melimpah setiap tahunnya membuat sektor ini memiliki kontribusi yang besar, bahkan dinilai menjadi penopang perekonomian utama Kabupaten Kepulauan Anambas.

Pada tahun 2018, kontribusi sektor Industri Pengolahan tidak lagi sebesar tahuntahun sebelumnya seperti yang terlihat pada Gambar 2. Hal ini dapat terjadi karena pengolahan minyak dan gas tidak lagi dilakukan di wilayah Kabupaten Kepulauan Anambas. Efeknya, terjadi perubahan struktur perekonomian dimana tahun-tahun sebelumnya sektor Industri Pengolahan menempati urutan kedua terbesar dengan kontribusi mencapai 10-11 persen, tapi tahun 2018 hanya sebesar 0,12 persen. Perubahan pada kontribusi sektor ekonomi di suatu wilayah dapat berpengaruh pada perubahan struktur perekonomian wilayah tersebut (Fatmawati \& Iskandar, 2019).

Sektor Pertanian, Kehutanan, dan Perikanan serta sektor Konstruksi menempati urutan kedua dan ketiga terbesar dalam kontribusinya bagi perekonomian Kabupaten Kepulauan Anambas pada tahun 2018. Sektor Perdagangan juga memiliki peranan cukup besar terhadap perekonomian Kabupaten Kepulauan Anambas karena sektor ini mampu menempati urutan keempat terbesar dalam kontribusinya bagi perekonomian wilayah ini.

Pertumbuhan ekonomi merupakan salah satu indikator makro untuk melihat kinerja perekonomian secara riil di suatu wilayah. Pertumbuhan ekonomi merupakan laju yang dibentuk dari berbagai faktor produksi yang terbagi menurut sektor ekonomi. Ukuran itu secara tidak langsung menggambarkan tingkat pertumbuhan ekonomi yang terjadi di suatu wilayah, tetapi dihitung berdasarkan perubahan PDRB atas dasar harga konstan tahun bersangkutan terhadap tahun sebelumnya. Pertumbuhan ekonomi juga dapat dipandang sebagai pertambahan jumlah barang dan jasa yang dihasilkan oleh semua sektor ekonomi selama satu tahun di suatu wilayah. 




Gambar 2. Distribusi PDRB Kabupaten Kepulauan Anambas menurut Lapangan Usaha Sumber: Data sekunder diolah, 2019.

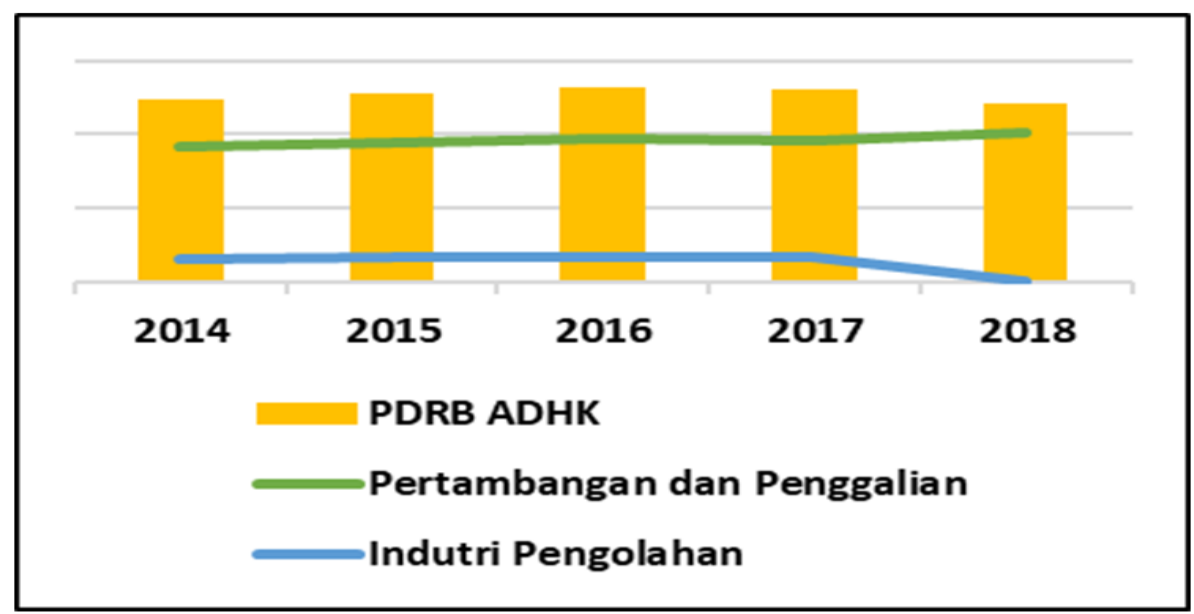

Gambar 3. Perbandingan PDRB ADHK, PDRB Sektor Pertambangan dan Penggalian, dan PDRB Sektor Industri Pengolahan Kabupaten Kepulauan Anambas

Sumber: Data sekunder diolah, 2019.

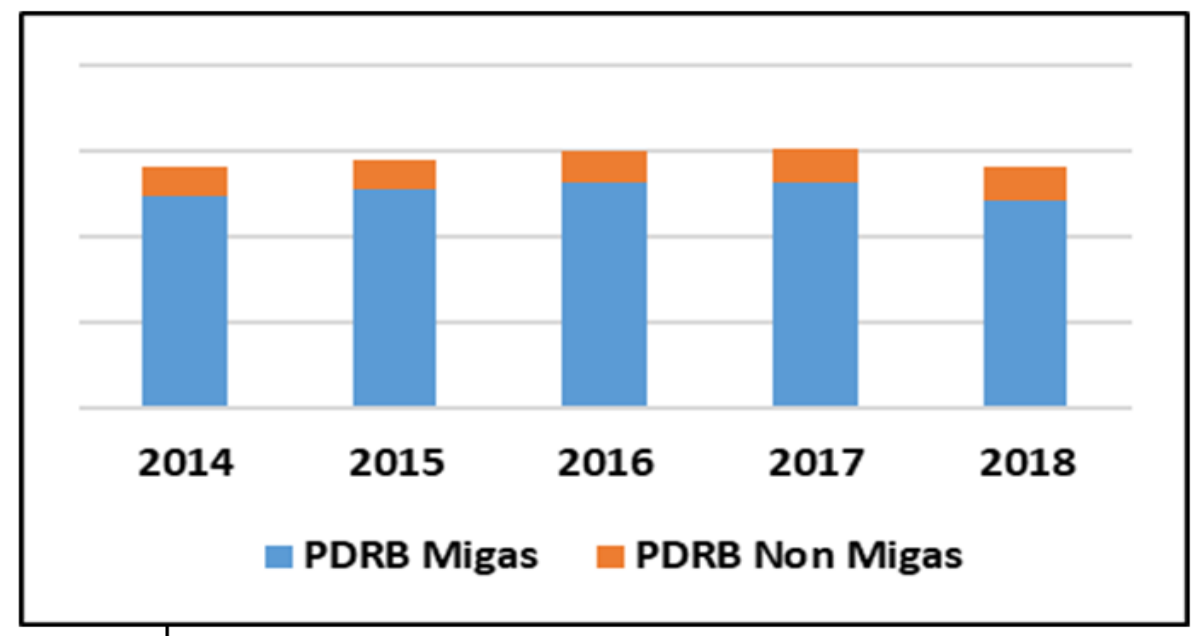

Gambar 4. PDRB Atas Dasar Harga Berlaku Kabupaten Kepulauan Anambas Sumber: Data sekunder diolah, 2019. 
Pertumbuhan ekonomi di Kabupaten Kepulauan Anambas senantiasa mengalami penurunan dalam lima tahun terakhir. Dari Gambar 3 terlihat bahwa seiring penurunan PDRB ADHK sektor Pertambangan dan Penggalian pada tahun 2017, PDRB ADHK total juga turut mengalami penurunan. Hal yang sama juga terjadi pada sektor Industri Pengolahan yang mengalami penurunan PDRB ADHK pada tahun 2018 dan diikuti dengan penurunan PDRB ADHK secara total. Hal ini menggambarkan dengan jelas pengaruh dari penurunan kedua sektor tersebut terhadap laju pertumbuhan PDRB. Mengingat bahwa laju pertumbuhan ekonomi Kabupaten Kepulauan Anambas bernilai negatif pada tahun 2017 dan 2018, maka dapat dikatakan bahwa terdapat kontribusi sektor Pertambangan dan Penggalian terhadap laju pertumbuhan ekonomi pada Kabupaten Kepulauan Anambas yang bernilai negatif pada tahun 2017 serta kontribusi sektor Industri Pengolahan terhadap laju pertumbuhan ekonomi Kabupaten Kepulauan Anambas pada tahun 2018. Dengan ini maka dapat pula dikatakan terdapat pengaruh kontribusi sektor migas terhadap laju pertumbuhan ekonomi Kabupaten Kepulauan Anambas yang bernilai negatif pada tahun 2017 dan 2018.

Besarnya kontribusi yang diberikan oleh sektor migas atas perekonomian Kabupaten Kepulauan Anambas mengakibatkan pergerakan pertumbuhan ekonomi bergantung pada arah pertumbuhan sektor ini sehingga pertumbuhan ekonomi menjadi sensitif terhadap nilai produksi migas setiap tahunnya. Hal ini menguntungkan apabila produksi migas dapat dipastikan meningkat setiap tahunnya, tetapi pada kenyataannya harga minyak dunia tidak menentu sehingga sulit mencapai kestabilan pertumbuhan ekonomi. Pertumbuhan sektor migas yang bernilai negatif tentu berdampak pada penurunan pertumbuhan ekonomi seperti yang terjadi pada Kabupaten Kepulauan Anambas selama tahun 2017-2018.

PDRB Kabupaten Kepulauan Anambas didominasi oleh sektor migas. Apabila melihat perkembangan rasio PDRB non migas terhadap PDRB migas, tergambar bahwa kontribusi sektor non migas terhadap nilai perekonomian Kabupaten Kepulauan Anambas mengalami peningkatan dari tahun ke tahun. Perkembangan sektor migas dan non migas dapat dilihat pada Gambar 4. Pada gambar tersebut terlihat bahwa nilai PDRB ADHB didominasi oleh sektor migas, tetapi kontribusinya terlihat mengalami penurunan. Sebaliknya, kontribusi sektor non migas justru terus mengalami kenaikan. Hal ini menggambarkan kinerja sektor non migas yang baik.

\section{Hasil Analisis LQ}

Berdasarkan Tabel 1, diperoleh hasil bahwa sektor Pertanian, Kehutanan, dan Perikanan serta sektor Pertambangan dan Penggalian memperoleh hasil LQ > 1 yang berarti kedua sektor tersebut merupakan sektor ekonomi unggulan. Namun, 15 sektor lainnya memperoleh hasil LQ $\leq 1$ yang mengindikasikan bahwa sektor-sektor tersebut tidak unggul dalam hal penyerapan tenaga kerja. Sektor-sektor tersebut adalah: Industri Pengolahan; Pengadaan Listrik dan Gas; Pengadaan Air, Pengelolaan Sampah, Limbah dan Daur Ulang; Konstruksi; Perdagangan Besar dan Eceran; Reparasi Mobil dan Sepeda Motor; Transportasi dan Pergudangan; Penyediaan Akomodasi dan Makan Minum; Informasi dan Komunikasi; Jasa Keuangan dan Asuransi; Real Estat; Jasa Perusahaan; Administrasi Pemerintahan, Pertahanan dan Jaminan Sosial Wajib; Jasa Pendidikan; Jasa Kesehatan dan Kegiatan Sosial; serta, Kegiatan Jasa Lainnya. 
Tabel 1. Hasil Analisis LQ Sektor Perekonomian Kabupaten Kepulauan Anambas Tahun 2018

\begin{tabular}{clc}
\hline No. & \multicolumn{1}{c}{ Sektor } & Hasil LQ \\
\hline 1. & Pertanian, Kehutanan, dan Perikanan & 1,612 \\
2. & Pertambangan dan Penggalian & 5,906 \\
3. & Industri Pengolahan & 0,003 \\
4. & Pengadaan Listrik dan Gas & 0,053 \\
5. & Pengadaan Air, Pengelolaan Sampah, Limbah dan Daur Ulang & 0,019 \\
6. & Konstruksi & 0,272 \\
7. & Perdagangan Besar dan Eceran; Reparasi Mobil dan Sepeda Motor & 0,262 \\
8. & Transportasi dan Pergudangan & 0,061 \\
9. & Penyediaan Akomodasi dan Makan Minum & 0,044 \\
10. & Informasi dan Komunikasi & 0,183 \\
11. & Jasa Keuangan dan Asuransi & 0,044 \\
12. & Real Estat & 0,402 \\
13. & Jasa Perusahaan & 0,032 \\
14. & Administrasi Pemerintahan, Pertahanan dan Jaminan Sosial Wajib & 0,721 \\
15. & Jasa Pendidikan & 0,122 \\
16. & Jasa Kesehatan dan Kegiatan Sosial & 0,221 \\
17. & Kegiatan Jasa Lainnya & 0,117 \\
\hline
\end{tabular}

Sumber: Data sekunder diolah, 2019.

LQ merupakan alat analisis yang dapat digunakan dengan mudan melalui proses perhitungan yang sangat sederhana. Hasil yang diperoleh pun dipengaruhi oleh berbagai faktor sehingga bisa saja perhitungannya bias, tergantung pada pemilihan peubah acuan, pemilihan tahun, serta kualitas data yang digunakan.

\section{Hasil Analisis Shift-Share}

Dari hasil analisis Shift-Share pada Tabel 2 terlihat bahwa terdapat dua sektor yang memiliki nilai $\mathrm{PS}_{\mathrm{ij}}$ dan $\mathrm{DS}_{\mathrm{ij}}$ yang positif $\left(\mathrm{PS}_{\mathrm{ij}}>0\right.$ dan $\left.\mathrm{DS}_{\mathrm{ij}}>0\right)$ yaitu sektor Konstruksi dan sektor Jasa Kesehatan dan Kegiatan Sosial. Dengan demikian, berdasarkan hasil analisis Shift-Share yang telah dilakukan itu, sektor Konstruksi dan sektor Jasa Kesehatan dan Kegiatan Sosial merupakan sektor dengan pertumbuhan sangat pesat di Kabupaten Kepulauan Anambas maupun di Provinsi Kepulauan Riau. Hal ini mengindikasikan bahwa kedua sektor itu merupakan sektor yang memiliki potensi untuk dikembangkan di Kabupaten Kepulauan Anambas.
Di sisi lain, terdapat sembilan sektor ekonomi yang pertumbuhannya terhambat tetapi masih berpotensi. Kesembilan sektor tersebut adalah: Pengadaan Listrik dan Gas; Perdagangan Besar dan Eceran, Reparasi Mobil dan Sepeda Motor; Transportasi dan Pergudangan; Penyediaan Akomodasi dan Makan Minum; Informasi dan Komunikasi; Jasa Keuangan dan Asuransi; Jasa Perusahaan; Administrasi Pemerintahan, Pertahanan dan Jaminan Sosial Wajib; serta, Jasa Pendidikan.

Sementara itu, sektor Pertanian, Kehutanan, dan perikanan serta sektor Real Estat merupakan dua sektor dengan level pertumbuhan terhambat tetapi berkembang. Kedua sektor tersebut memiliki daya saing yang tinggi apabila dibandingkan dengan sektor lain di Kabupaten Kepulauan Anambas. Tetapi apabila kedua sektor itu dibandingkan dengan sektor yang sama di Provinsi Kepulauan Riau, maka dinilai pertumbuhannya lebih lambat. 
Tabel 2. Hasil Analisis Shift-Share Sektor Perekonomian Kabupaten Kepulauan Anambas Tahun 2018

\begin{tabular}{clcc}
\hline \multicolumn{1}{c}{ Sektor } & $\mathrm{PS}_{\mathrm{ij}}$ & $\mathrm{DS}_{\mathrm{ij}}$ \\
\hline No. & & - & + \\
1. & Pertanian, Kehutanan, dan Perikanan & - & - \\
2. & Pertambangan dan Penggalian & - & - \\
3. & Industri Pengolahan & + & - \\
4. & Pengadaan Listrik dan Gas & - & - \\
5. & Pengadaan Air, Pengelolaan Sampah, Limbah dan Daur Ulang & + & + \\
6. & Konstruksi & + & - \\
7. & Perdagangan Besar dan Eceran; Reparasi Mobil dan Sepeda Motor & + & - \\
8. & Transportasi dan Pergudangan & + & - \\
9. & Penyediaan Akomodasi dan Makan Minum & + & - \\
10. & Informasi dan Komunikasi & + & - \\
11. & Jasa Keuangan dan Asuransi & - & + \\
12. & Real Estat & + & - \\
13. & Jasa Perusahaan & + & - \\
14. & Administrasi Pemerintahan, Pertahanan dan Jaminan Sosial Wajib & + & - \\
15. & Jasa Pendidikan & + & + \\
16. & Jasa Kesehatan dan Kegiatan Sosial & - & - \\
17. & Kegiatan Jasa Lainnya & & \\
\hline
\end{tabular}

Sumber: Data sekunder diolah, 2019.

Hasil analisis juga menunjukkan empat sektor lainnya merupakan sektor yang memiliki daya saing rendah dan juga peranannya terhadap wilayah rendah. Keempat sektor ini bukan merupakan sektor yang potensial.

\section{Hasil Analisis Tipologi Klassen}

Tabel 3 memperlihatkan bahwa hanya sektor Pertanian, Kehutanan, dan Perikanan yang diklasifikasikan sebagai sektor unggulan dan tumbuh pesat; sedangkan sektor pertambangan diklasifikasikan sebagai sektor unggulan tetapi pertumbuhannya tertekan. Terdapat tiga sektor yang potensial dan masih dapat dikembangkan, yaitu Konstruksi, Real Estat, serta Aktivitas Kesehatan Manusia dan Kegiatan Sosial.

Sementara itu, sebanyak 12 sektor dianalisis bukan merupakan sektor potensial. Sektor-sektor itu adalah: Industri Pengolahan; Pengadaan Listrik dan Gas; Perdagangan Besar dan Eceran; Reparasi Mobil dan Sepeda Motor; Transportasi dan Pergudangan; Penyediaan Akomodasi dan Makan Minum; Informasi dan Komunikasi; Jasa Keuangan dan Asuransi; Jasa Perusahaan; Administrasi Pemerintahan, Pertahanan dan Jaminan Sosial Wajib; Jasa Pendidikan; serta, Kegiatan Jasa Lainnya.

\section{Pembahasan}

Pertumbuhan Ekonomi Kabupaten Kepulauan Anambas mengalami kontraksi karena adanya pertumbuhan negatif pada sektor migas yang memiliki kontribusi terbesar dalam perekonomian. Hal ini menjadi peringatan bagi pemerintah bahwa Kabupaten Kepulauan Anambas tidak bisa bergantung pada sektor migas saja. Perlu adanya strategi untuk meningkatkan sektor-sektor ekonomi lainnya, terutama sektor unggulan, sehingga perekonomian tidak menjadi sensitif terhadap pergerakan sektor migas.

Hasil analisis dengan menggunakan tiga metode di atas dapat dirangkum seperti yang ditampilkan pada pada Tabel 4. Terdapat dua sektor ekonomi yang merupakan kategori unggulan. yaitu sektor Pertanian, Kehutanan, dan Perikanan serta sektor Pertambangan dan Penggalian. 
Tabel 3. Klasifikasi Pertumbuhan Ekonomi menurut Tipologi Klassen di Kabupaten Kepulauan Anambas Tahun 2018

\begin{tabular}{|c|c|c|c|c|c|c|}
\hline No. & Sektor & $\mathrm{S}_{\mathrm{i}}$ & $\mathrm{S}$ & $\overline{G_{i}}$ & G & Kesimpulan \\
\hline 1. & Pertanian, Kehutanan, dan Perikanan & 5,232 & 3,246 & 41,727 & 27,50 & $\begin{array}{l}\text { Sektor unggulan dan } \\
\text { tumbuh pesat }\end{array}$ \\
\hline 2. & Pertambangan dan Penggalian & 83,536 & 14,144 & 20,246 & 31,24 & $\begin{array}{l}\text { Sektor unggulan tapi } \\
\text { pertumbuhannya } \\
\text { tertekan }\end{array}$ \\
\hline 3. & Industri Pengolahan & 0,120 & 36,865 & $-98,916$ & 54,15 & Bukan sektor potensial \\
\hline 4. & Pengadaan Listrik dan Gas & 0,056 & 1,065 & 52,173 & 68,50 & Bukan sektor potensial \\
\hline 5. & $\begin{array}{l}\text { Pengadaan Air, Pengelolaan } \\
\text { Sampah, Limbah dan Daur Ulang }\end{array}$ & 0,002 & 0,117 & 35,872 & 46,10 & Bukan sektor potensial \\
\hline 6. & Konstruksi & 5,096 & 18,720 & 100,337 & 74,62 & $\begin{array}{l}\text { Sektor potensial dan } \\
\text { masih dapat } \\
\text { dikembangkan }\end{array}$ \\
\hline 7. & $\begin{array}{l}\text { Perdagangan Besar dan Eceran; } \\
\text { Reparasi Mobil dan Sepeda Motor }\end{array}$ & 2,322 & 8,863 & 65,530 & 83,43 & Bukan sektor potensial \\
\hline 8. & Transportasi dan Pergudangan & 0,187 & 3,065 & 52,104 & 58,78 & Bukan sektor potensial \\
\hline 9. & $\begin{array}{l}\text { Penyediaan Akomodasi dan Makan } \\
\text { Minum }\end{array}$ & 0,100 & 2,260 & 69,765 & 87,57 & Bukan sektor potensial \\
\hline 10. & Informasi dan Komunikasi & 0,371 & 2,024 & 60,147 & 81,02 & Bukan sektor potensial \\
\hline 11. & Jasa Keuangan dan Asuransi & 0,121 & 2,735 & 43,315 & 64,44 & Bukan sektor potensial \\
\hline 12. & Real Estat & 0,557 & 1,388 & 51,744 & 42,89 & $\begin{array}{l}\text { Sektor potensial dan } \\
\text { masih dapat } \\
\text { dikembangkan }\end{array}$ \\
\hline 13. & Jasa Perusahaan & 0,000 & 0,005 & 59,813 & 68,12 & Bukan sektor potensial \\
\hline 14. & $\begin{array}{l}\text { Administrasi Pemerintahan, } \\
\text { Pertahanan dan Jaminan Sosial Wajib }\end{array}$ & 56 & 76 & 77 & 62,24 & Bukan sektor potensial \\
\hline 15. & Jasa Pendidikan & 0,184 & 1,502 & 38,516 & 59,36 & Bukan sektor potensial \\
\hline 16. & Jasa Kesehatan dan Kegiatan Sosial & 0,198 & 0,896 & 81,997 & 56,83 & $\begin{array}{l}\text { Sektor potensial dan } \\
\text { masih dapat } \\
\text { dikembangkan }\end{array}$ \\
\hline 17. & Kegiatan Jasa Lainnya & 0,062 & 0,530 & 21,234 & 55,63 & Bukan sektor potensial \\
\hline
\end{tabular}

Sumber: Data sekunder diolah, 2019.

Mengingat area Kabupaten Kepulauan Anambas dikelilingi oleh laut dan nelayan merupakan mata pencaharian sebagian besar masyarakat, maka pemerintah sebaiknya memberi perhatian pada sektor Pertanian, Kehutanan, dan Perikanan khususnya dalam peningkatan produktivitas hasil perikanan sehingga dapat pula meningkatkan sektor lainnya yang berkaitan dan dapat mendongkrak pertumbuhan ekonomi. Tingginya produksi hasil laut dapat mendorong aktivitas pengolahan hasil laut sehingga sektor industri pengolahan turut mengalami peningkatan. Hal ini tentu dapat berdampak pada peningkatan ekspor hasil laut ke luar wilayah Kabupaten
Kepulauan Anambas. Apabila hasil laut dimanfaatkan secara optimal, maka dapat meningkatkan pendapatan daerah maupun kesejahteraan masyarakat daerah itu.

Selain itu, terdapat 12 sektor ekonomi yang merupakan kategori sektor potensial, yaitu: Industri Pengolahan; Pengadaan Listrik dan Gas; Perdagangan Besar dan Eceran; Reparasi Mobil dan Sepeda Motor; Transportasi dan Pergudangan; Penyediaan Akomodasi dan Makan Minum; Informasi dan Komunikasi; Jasa Keuangan dan Asuransi; Jasa Perusahaan; Administrasi Pemerintahan, Pertahanan dan Jaminan Sosial Wajib; Jasa Pendidikan; dan Kegiatan Jasa Lainnya. 
Tabel 4. Ringkasan Hasil Penghitungan LQ, Analisis Shift-Share, dan Tipologi Klassen Menurut Sektor di Kabupaten Kepulauan Anambas Tahun 2018

\begin{tabular}{|c|c|c|c|c|c|c|}
\hline \multirow{2}{*}{ No. } & \multirow{2}{*}{ Sektor } & \multirow{2}{*}{ LQ } & \multicolumn{2}{|c|}{ Shift-Share } & \multirow{2}{*}{ Klassen } & \multirow{2}{*}{ Kesimpulan } \\
\hline & & & $\mathrm{PS}_{\mathrm{ij}}$ & $\mathrm{DS}_{\mathrm{ij}}$ & & \\
\hline 1. & Pertanian, Kehutanan, dan Perikanan & + & - & + & KW1 & Unggulan \\
\hline 2. & Pertambangan dan Penggalian & + & - & - & KW2 & $\begin{array}{l}\text { Unggulan tapi } \\
\text { pertumbuhannya } \\
\text { tertekan }\end{array}$ \\
\hline 3. & Industri Pengolahan & - & - & - & KW3 & $\begin{array}{l}\text { Masih dapat } \\
\text { dikembangkan }\end{array}$ \\
\hline 4. & Pengadaan Listrik dan Gas & - & + & - & KW3 & Potensial \\
\hline 5. & $\begin{array}{l}\text { Pengadaan Air, Pengelolaan } \\
\text { Sampah, Limbah dan Daur Ulang }\end{array}$ & - & - & - & KW3 & $\begin{array}{l}\text { Masih dapat } \\
\text { dikembangkan }\end{array}$ \\
\hline 6. & Konstruksi & - & + & + & KW4 & Potensial \\
\hline 7. & $\begin{array}{l}\text { Perdagangan Besar dan Eceran; } \\
\text { Reparasi Mobil dan Sepeda Motor }\end{array}$ & - & + & - & KW3 & Potensial \\
\hline 8. & Transportasi dan Pergudangan & - & + & - & KW3 & Potensial \\
\hline 9. & $\begin{array}{l}\text { Penyediaan Akomodasi dan Makan } \\
\text { Minum }\end{array}$ & - & + & - & KW3 & Potensial \\
\hline 10. & Informasi dan Komunikasi & - & + & - & KW3 & Potensial \\
\hline 11. & Jasa Keuangan dan Asuransi & - & + & - & KW3 & Potensial \\
\hline 12. & Real Estat & - & - & + & KW4 & Potensial \\
\hline 13. & Jasa Perusahaan & - & + & - & KW3 & Potensial \\
\hline 14. & $\begin{array}{l}\text { Administrasi Pemerintahan, } \\
\text { Pertahanan dan Jaminan Sosial Wajib }\end{array}$ & - & + & - & KW3 & Potensial \\
\hline 15. & Jasa Pendidikan & - & + & - & KW3 & Potensial \\
\hline 16. & Jasa Kesehatan dan Kegiatan Sosial & - & + & + & KW4 & Potensial \\
\hline 17. & Kegiatan Jasa Lainnya & - & - & - & KW3 & $\begin{array}{l}\text { Masih dapat } \\
\text { dikembangkan }\end{array}$ \\
\hline
\end{tabular}

Sumber: Data sekunder diolah, 2019.

\section{SIMPULAN}

Berdasarkan hasil analisis LQ, ShiftShare, maupun Tipologi Klassen, dapat disimpulkan dua hal utama. Pertama, sektor Pertanian, Kehutanan, dan Perikanan merupakan sektor ekonomi unggulan karena sektor ini bertumbuh pesat. Kedua, sektor Pertambangan dan Penggalian adalah sektor unggulan tetapi pertumbuhannya tertekan.

Berdasarkan kesimpulan tersebut, bisa direkomendasikan beberapa hal. Pertama, Pemerintah Kabupaten Kepulauan Anambas agar fokus dalam peningkatan kinerja sektor Pertanian, Kehutanan, dan Perikanan karena tersedianya sumber daya alam yang melimpah di bidang perikanan.

Kedua, pemerintah sebaiknya juga memberi fokus pada sektor ekonomi yang dikategorikan sebagai sektor-sektor potensial, seperti: Industri Pengolahan; Pengadaan Listrik dan Gas; Perdagangan Besar dan Eceran; Reparasi Mobil dan Sepeda Motor; Transportasi dan Pergudangan; Penyediaan Akomodasi dan Makan Minum; Informasi dan Komunikasi; Jasa Keuangan dan Asuransi; Jasa Perusahaan; Administrasi Pemerintahan, Pertahanan dan Jaminan Sosial Wajib; Jasa Pendidikan; serta, Kegiatan Jasa Lainnya.

Ketiga, diperlukan adanya penelitianpenelitian lanjutan yang lebih mendalam untuk mengetahui sektor-sektor unggulan di Kabupaten Kepulauan Anambas menggunakan alat analisis lain. Selain itu, diperlukan adanya penelitian yang berkelanjutan agar dapat diketahui perkembangan sektor-sektor 
ekonomi dari tahun ke tahun, baik yang diklasifikasikan sebagai sektor unggulan, potensial, maupun yang tidak potensial.

\section{REFERENSI}

Adhitama, O., Santoso, B. \& Riyanto. 2014. Kontribusi Sektor Migas terhadap Penerimaan Daerah Dalam Rangka Meningkatkan Pembangunan Daerah di Kabupaten Bojonegoro. Jurnal Administrasi Publik (JAP). 2(3): 492-498.

Aditama, R. 2018. Pengembangan Potensi Ekonomi dan Penetapan Sektor Unggul di Provinsi Jawa Timur Wilayah Utara. Media Ekonomi. 26(2): 127-136.

Amalia, F. 2012. Penentuan Sektor Unggulan Perekonomian Wilayah Kabupaten Bone Bolango dengan Pendekatan Sektor Pembentuk PDRB. Jurnal Etikonomi. 11(2): 196-207.

Desrindra, I., Murialti, N. \& Anriva, D.H. 2016. Analisis Faktor yang Mempengaruhi Indeks Pembangunan Manusia di Provinsi Riau. Jurnal Akuntansi \& Ekonomika. 6(2): 98-107.

Emilia, Syaifuddin, dan Nurjanah, R. 2014. Analisis Tipologi Pertumbuhan Sektor Ekonomi Basis dan Non Basis dalam Perekonomian Propinsi Jambi. Jurnal Paradigma Ekonomika. 9(2): 1-8.

Fatmawati, A. \& Iskandar, D.D. 2019. Analisis Perubahan Struktur Ekonomi (Economic Landscape) Jawa Tengah (Analisis Input-Output Periode Tahun 2000-2013). Jurnal Dinamika Ekonomi Pembangunan. 1(3): 46-70.

Firdaus. 2007. Ekonomi Regional. Jakarta: Universitas Terbuka.

Hajeri, Yurisinthae, E. \& Dolorosa, E. 2015. Analisis Penentuan Sektor Unggulan Perekonomian di Kabupaten Kubu Raya. Jurnal Ekonomi Bisnis dan Kewirausahaan. 4(2): 253-269.

Husna, N., Noor, I. \& Rozikin, M. 2013. Analisis Penentuan Sektor Unggulan Perekonomian di Kabupaten Kubu Raya. Jurnal Administrasi Publik. 1(1): 188-196.
Jumiyanti, K.R. 2018. Analisis Location Quotient dalam Penentuan Sektor Basis dan Non Basis di Kabupaten Gorontalo. Gorontalo Development Review. 1(1): 29-43.

Kharisma, B. \& Hadiyanto, F. 2018. Penentuan Potensi Sektor Unggulan dan Potensial di Provinsi Maluku. Jurnal Ekonomi \& Studi Pembangunan. 19(1): 21-34.

Marfiani, T., Hartoyo, S. \& Manuwoto. 2009. Analisis Potensi Ekonomi dan Strategi Pembangunan Ekonomi di Bogor Barat. Jurnal Manajemen Pembangunan Daerah. 1(1): 1-16.

Mose, B.E.P.J., Engka, D.S.M. \& Tolosang, K.D. 2016. Analisis Potensi Perekonomian Wilayah Kabupaten Kepulauan Sangihe. Jurnal Berkala Ilmiah Efisiensi. 16(1): 680-693.

Nugroho, S. 2004. Model Ekonomi Basis untuk Perencanaan Pembangunan Daerah. Jurnal Dinamika Pembangunan. 1(1): 23-30.

Nurlina, Andiny, P. \& Sari, M. 2019. Analisis Sektor Unggulan Aceh Bagian Timur. Jurnal Samudra Ekonomi dan Bisnis. 10(1): 23-37.

Rahmatullah. 2012. Struktur Ekonomi dan Sektor Unggulan Sektoral Pada Propinsi Riau. Jurnal Signifikan. 1(1): 53-64.

Rochmaningrum, F. 2012. Perkembangan Tambang Minyak Blok Cepu dan Pengaruhnya terhadap Sosial Ekonomi Masyarakat Desa Ledok Tahun 19602004. Journal of Indonesian History. 1(2): 92-99.

Roziqin. 2015. Pengelolaan Sektor Minyak Bumi di Indonesia Pasca Reformasi: Analisis Konsep Negara Kesejahteraan. Jurnal Tata Kelola \& Akuntabilitas Keuangan Negara. 1(2): 128-140.

Sahid, A., Hamid, E.S. \& Armawi, A. 2019. Dampak Implementasi Asas Cabotage dan Program Tol Laut Terhadap Ketahanan Wilayah (Studi di Kabupaten Kepulauan Anambas, Provinsi Kepulauan Riau). Jurnal Ketahanan Nasional. 25(2): 131-150. 
Suryani, E. 2006. Analisis Total Faktor Produktivitas dan Pertumbuhan Ekonomi Sumatera Selatan. Jurnal Akuntansi \& Ekonomika. 6(2): 98-107.

Tambunan, T.T.H. 2001. Perekonomian Indonesia: Teori dan Temuan Empiris. Jakarta: Ghalia Indonesia.

Umiyati, E. 2014. Analisa Pertumbuhan Ekonomi dan Ketimpangan Pembangunan Antar Wilayah di Pulau Sumatera. Jurnal Paradigma Ekonomika. 9(2): 42-50.
Yulianita, A. 2009. Analisis Sektor Unggulan dan Pengeluaran Pemerintah di Kabupaten Ogan Komering Ilir. Jurnal Ekonomi Pembangunan. 7(2): 70-83.

Yulianita, A. 2010. Analisis Sektor Ekonomi Unggulan di Kabupaten Muara Enim. Jurnal Ekonomi Pembangunan. 8(2): 98-113 